\title{
INDIGENOUS BELIEFS AND PRACTICES IN ECOSYSTEM CONSERVATION: RESPONSE OF THE CHURCH ${ }^{1}$
}

\author{
Yaw Adu-Gyamfi \\ School of Theology and Ministry \\ Ghana Baptist University College
}

\begin{abstract}
The Akan people of Ghana's beliefs and practices, enforced by taboos regarding ecosystem conservation, foster a sustainable use of the environment. Akan beliefs and practices highlight their moral import, are crucial in preserving the environment, and protect water sources, the natural vegetation and wildlife and endangered nonhuman species. However, the church has not taken the indigenous beliefs, practices and taboos seriously. The decline of these has led to the degradation of the Ghanaian environment. This article aims at drawing the church's attention by arguing that the indigenous beliefs and practices are more earth-friendly and consistent with biodiversity than modern or Western ways of life and that they represent the best chance for successful ecological practices that enhance ecosystem conservation.
\end{abstract}

Keywords: Indigenous, Environment, Taboos, Church

\section{Introduction}

The ecological crisis has become a matter of concern globally. From various quarters, attention is drawn to the harm human beings and their activities do to the environment, the consequences of the situation upon human life and the need to arrest this menace. Environmental conservation is not a recent phenomenon in indigenous Ghanaian communities. Past generations knew about environmental degradation and the need for preservation. This article aims to show that Ghanaian indigenous beliefs, cultural taboos and their sanctions have helped to check abuse of the environment by indigenous people in the past. The article also seeks to show that the disregard for these traditional checks and balances, especially among Christians, has adversely affected their enforcement in our contemporary era. The article concludes that the church has a duty to play in the conservation of the environment and that one such duty is to respect traditional beliefs and their sanctions in ecosystem conservation. Since Ghana is composed of various ethnic communities I have chosen to use the Akans' indigenous beliefs and practices, because they are not different from those of other ethnic groups.

\section{The Akan Universe ${ }^{2}$}

To understand the Akans' indigenous beliefs and practice in ecosystem conservation we need to begin from the Akan concept of the universe. The Akans believe that the universe

1 This contribution is based on a paper presented at a conference on "Church and Environment", hosted by the Ghana Baptist University College in Kumasi, Ghana, 25-29 April 2011.

2 See Adu-Gyamfi (2007). 
consists of both visible and invisible realities and that it was created by Onyankropon (the Supreme Being), who controls, sustains and upholds it. The Akans, therefore, perceive the universe and life within it in terms of religion. The implication of this outlook is that everything in the universe, both visible and invisible, is religiously interpreted. Thus, the social, political and economic institutions and aspirations are closely linked to the people's assumptions, beliefs and interpretations of the universe - God, humankind, society and nature. The Akan universe contains numerous participants - spirits, humans, animals and plants. ${ }^{3}$ The Akan mind perceives the universe as a 'forest of symbols' in which the sacred is believed to pervade and manifest itself in and through all of nature, animate and inanimate.

Another important aspect of the Akan concept of the universe is that the visible world depends on the invisible world so that the sacred and mundane cannot be dichotomized. The spirit world and the material world are not two independent worlds. One has no meaning without the other; they complement each other. However, it is the spirit beings that control the material world; the material world is an arena in which the various categories of spiritual beings display their powers. Human beings are dependent upon these spiritual beings for their needs, while the spirit beings need humans to gladden their hearts, to feed them (Ezeanya 1969:36). It is imperative to mention here that between these two worlds, there is order, not chaos. This relationship stresses the importance of the spirit world to the Akan: no human pursuit can be accomplished without it being secured successfully first in the spiritual realm. This relationship leads to the belief that the political organization of the secular realm reflects that of the spiritual (Assimeng 1981:34).

The Akan universe is filled with power. Nyankropon created a universe impregnated with his power (Gyekye 1987:75), and individuals and groups who successfully tap into this power source translate this access into authority if they control social institutions (Akyeampon and Obeng 1995:483). Thus is grounded the authority of chiefs, priests and priestesses and medicine men and women.

For the Akans, the universe is living because the divine is actively involved in it. The universe is conceived as 'theocratic' not 'anthropocentric'. The human being is simply part of the whole, a responsible part and not owner of the other parts. As Asante (1995:74) notes, Akans do not see themselves as inside the world, but as forming part of the world. Reality is both relational and interrelational. The Akan people do not make sharp distinction between the self and the world, humankind and nature, subjects and objects: these are one reality.

\section{Akan Beliefs and Practices on the Environment}

As a result of their view of the universe, the Akans believe that the natural environment is a living phenomenon. Akans practice what Ongong' (1994:67) terms 'cosmocracy' in which human beings are not more important than the natural environment. The traditional culture of Akan stresses a strong relationship with the environment. Thus the impact of Akan view of the universe is that they have developed deep respect for nature and interact with it.

As a result, in the past a culturally acceptable environmental management in the form of strictures and taboos related to water bodies, land and deep forest was put in place. The cultural practices served the important purpose of conserving nature. This to a large extent

Note that Akans believe that some animals and plants possess a potent life-force, sasa, but they do not necessarily make these objects of worship. However, such spiritually powerful animals and plants were treated with great circumspection. 
helped save the environment and our ancestors rarely died of pollution-related ailments. With the advent of Christianity, Islam, civilization and its accompanying technology in Ghana, however, many of these beliefs, taboo, customs and traditions have been relegated to the background and are regarded by many, especially Christians, as fetishes and useless, demonic and satanic, though they played a key role in environmental protection.

\section{Taboos as Ecological Guardians}

Taboos were used by our ancestors to protect the ecosystem. The word, taboo is derived from the Polynesian term tabu, which means 'forbidden'. The closest equivalents to tabu in the Akan areakyiwadee, i.e., that which is forbidden or prohibited, and mmusuo, usually reserved for prohibitions against very grievous evils. Taboos represent unwritten social rules that regulate human behaviour. Such constraints not only govern human social life, but may also affect, and sometimes even directly manage, many constituents of the local natural environment. Whatever the reason for such constraints, taboos may, at least locally, play a major role in the conservation of natural resources, species, and ecosystems (Johannes 1978, 1982, 1984; Chapman 1985, 1987; Gadgil 1987).

No matter how trivial or absurd taboos may appear to the modern mind in details, they contain within them "germinant principles of social progress and moral order" and so "the cornerstone of the whole social order" (Cassier 1992:106). There was no part of the social system that was not regulated and governed by taboos. The taboo system was the main source of bonding in all human relations and transactions. Eventually they were assimilated into the great religions by religious leaders who made obeying such restrictions and obligations religious obligations (Cassier 1992:108). Unfortunately, Cassier discarded taboos associated with African beliefs and practices as 'savage taboos' and so marginalized from moral discourse, since African Traditional Religion (ATR) is not considered among the major religions. My analysis of some of Akan environmental taboos will show that, on the contrary, taboos associated with ATR are not savage because they have rational and scientific explanations and moral principles.

Akan ancestors understood human psychology, and knowing the environment in which people had been brought up, they capitalised on this situation and invoked the inhibitions, fears, awe and all other emotions associated with this psychological status when they had to make important pronouncements or establish a festival, code of conduct or practice which had to be observed by the people. They knew that this was the most effective way of ensuring compliance.

\section{Akan Beliefs and Practices in Ecosystem Conservation}

Here attention is given to the various forms of scientific taboos and how they are used in traditional societies for promoting biodiversity. I argue that behind the facade of the wellknown personal or mystical explanation, there are profound scientific or rational explanations with notable implications for biodiversity.

Traditional authorities used taboos for regulating the ethical use of the environment in view of its resources for the ecology and sustainable development. The examples in most Akan communities include: clearing of sacred forest or bushes, felling of forbidden timber species, hunting of animals or fishing during forbidden seasons and sacred days, eating of totem animal such as tortoise, parrots and eagles, eating of sacred animals or fish, digging of graves for burial with due authorization from the chief or other traditional authorities and washing clothes in streams and fetching water with silverware. According to the elders, 
violating any of these taboos incurs the wrath of the ancestors and gods, including the earth goddess, Asaase Yaa, and the goddess of the sea, Maame Wata.

\section{Conservation of Land}

Among Akans land is sacred and a gift from God through the ancestors to be preserved and used on a sustainable basis for the good of the community - past, present and future. In view of this, among the Akans it is forbidden to sell land outright. Rather, it is leased, and the ancestors are to be informed whenever land is leased.

In addition, the Akans perceive land as Mother Earth, a living goddess, who needs a day of rest. So, in various communities weekly 'Sabbaths' are observed for the land. On such days, inhabitants do not go to farm. This weekly 'Sabbath' clearly reduces the risk of over exploitation of the land and, in addition gives the farmer time to rest.

Furthermore, restrictions were put on cultivation of a piece of land. Certain plants were used as indicators of soil quality. The appearance of some plants on the land indicated that the land needed to regenerate, and so it was left fallow. Similarly, the appearance of certain other plants later on indicated that land had been sufficiently regenerated and was ready for re-cropping (Garbrah 2000:68). This restriction of the use of land was what is scientifically called 'shifting cultivation'. The restriction was no doubt employed to ensure sustainability.

\section{Conservation of forests - Sacred Groves}

Sacred groves in many communities demonstrate the sense of ecology of our ancestors. Sacred groves include patches of forest lands, on water catchment areas in hilly slopes, river beds and river edges. They are areas set aside as sacred sites and strictly protected by customary laws, beliefs and enforced taboos. Chiefs, communities or individuals for religious and cultural purposes have reserved these areas for purposes such as royal burial grounds, preservation of watercourses and sacred plants and the abodes for traditional deities.

Sacred groves have assisted the protection of rivers and streams and fishes in them, rare species of plants and animals, fragile ecosystems and prime forest. Examples of such groves are the Buoyam Sacred Grove and the Buaben-Fiema Monkey Sanctuary.

The Buoyam Sacred Grove is situated in the Techiman district of Brong Ahafo. According to the Ghana Association for the Conservation of Nature (GACON), the grove is 3694 hectares. They describe the grove as remnant dry semi-deciduous and savannahtransition zone forest. The River Mprisi flows through part of the grove. The grove provides sanctuary for much wildlife now absent from the surrounding land, GACON reports show that the grove contains a diverse fauna, including a large colony of fruit bats where over 20,000 roost in a series of underground caves. Rodents and avifauna abound, which is typical of such transitional vegetation that offers varied habitats for both forest and grassland species. It is important to note that the grove was established as far back as the 14th century, initially to protect bats, which were food for the traditional authorities (stools). Sadly, however, this grove was under intense threat from degradation due to fire, encroachment, hunting and collection of firewood. We thank God for the intervention of GACON to save the grove. GACON assisted the community to conserve and effectively manage their grove through protection from bush fire, promoting alternative incomes and increasing public awareness of the importance of conserving sacred groves. GACON worked with the Buoyam community by building a strong relationship with the chief, elders and members of the community. GACON concluded its reports on this note: 
The local traditions are as important as the project itself. The right of the people to continue with their customs and traditional rites are paramount and hold priority over the actual conservation of the forest.

The Buaben-Fiema Monkey Sanctuary is located within the moist forest deciduous zone. It is richer than any other Ghanaian forest in the area in diverse types and rare species of monkeys such as the Colobus polykomos (black and white colobus) and Cercopithecus campbelli (mona monkey). These monkeys are considered sacred by the local people of Buaben and Fiema villages. The unharmed monkeys, referred to as 'children of the gods', have for hundreds of years come into the villages daily to eat and play. The sanctuary is rich in trees; about 125 known species, including such rare ones as Pericopsis Elata.

It is on record that over $80 \%$ of sacred groves in Ghana serve as watersheds for catchment areas where they protect sources of drinking water. At present, about $1.5 \%$ of Ghana's land is covered by some 2000 sacred groves. Permit me to say that although sacred groves are associated with religious beliefs and practices, we should not ignore their ecological value. They have become natural breeding grounds for fauna and flora. Our ancestors instilled religious fear in order to ensure the preservation of the groves.

\section{Water}

- Sacred water bodies and fishes

Among Ghanaian communities some parts of water bodies are sacred. In some communities it is prohibited to fish in particular parts of a river. In such parts fish grow to bigger sizes and in large numbers, and because "most river fishes are not sessile, the sacred sections of the river serves as breeding grounds for fishes found elsewhere in the river" (Garbrah 2000:70). Similarly, where the entire river or stream is sacred, the river or stream becomes a breeding ground for tributaries of these sacred rivers, as in Ejuso and Nyinahin.

Another good example is a river in Wansamire. It is forbidden to fish in this river for sale. The local people, however, are allowed to fish for domestic consumption. Because of this restriction, the river is full of various fishes. There may be religious reasons for this restriction; there is certainly ecological reason - fishing for domestic consumption only prevents overconsumption that can easily deplete the fish in this river.

\section{- Non-sacred water issues}

Sacredness aside, in the past, our ancestors used a very astute way to protect the water bodies and avoided many water related diseases. Those part of the river used for bathing, swimming, or for watering crops and washing domestic animals were located downstream in relation to those used as sources of drinking water. In an effort to minimize water pollution from household waste and to reduce the quick spread of water-borne diseases, communities were often situated more than half a mile away from rivers and lakes. Since the distance makes the drawing of drinking water an arduous task, water conservation was a common tradition.

Moreover, there were taboos to prevent the use of metal implements in lakes and rivers. Clay pots rather than metal-ware were used to fetch water. Metallic elements in rivers could kill fish. Fish such as tuna, that could swallow metal objects could transfer metallic elements to humans on consumption, leading to sickness and even death.

Furthermore, it was prohibited to wash clothes in streams. This has conservation purposes. In olden days the locally made soap was chemically powerful enough to kill marine 
life. Finally, in addition to taboos, special community labours were organized for the clearing of weeds and debris along river banks and for deepening sources of drinking water.

\section{The Sea}

Communities of the Central and Western coastal regions of Ghana perceive the sea as goddess, Maame wata (Mother Water). In such communities it is forbidden to go to the sea on Tuesday, because Tuesday is considered the day of the goddess. It is believed that on Tuesdays the goddess has time with her children, which were mostly fish. In order not to disturb the goddess and her children it was strictly taboo for anyone to go fishing on that day. Though this may sound unscientific, many who disobeyed these directives and went on fishing on those days were drowned. It was also forbidden to go fishing at certain periods of the year in many fishing communities. From the scientific point of view, these free periods enhanced fish reproduction and also protected fingerlings from being caught. It was also forbidden to eat certain types of fish; even if they were caught, they were freed because they were regarded as beloved children of the goddess. Current scientific investigation has shown that such fish have a low productivity rate and intense harvesting may cause their extinction. Our ancestors had no scientific knowledge when they passed some of these rules, yet they were able to preserve these vulnerable fish species.

\section{Game}

Communities that are located in the forest zones of Ghana forbid hunting in the forest on some days and at some periods of the year. It was taboo for a hunter to kill an animal and refuse to eat it. It was an even worse offence for a farmer or hunter to kill game that is young, pregnant or fending for their young ones. It was believed that Asaase Yaa, goddess of the earth, would strike the defaulter to death instantly. It was also believed that such a person might not have children or lose his children if he kills a pregnant or young animal. It was considered a bad omen to kill a pregnant animal. All these taboos were to promote reproduction of game and to prevent their extinction.

\section{Trees}

In the forest zones, it was forbidden to fell some trees without the knowledge of the chief or priest. It was believed that blood would ooze out of the tree if cut. Such trees, cedars, for instance, were not plentiful in the forest. Therefore the restriction preserved the few in the forest.

Clearly, traditional Akan peasants knew that cutting all or most of the available forest will not only deprive the future generations of rare plants and animals, but will also affect the delicate balance between plants, animals and humans with their needs for food, medicine, space, clean water and clean air. This means that environmental consciousness had been part of the traditional Akan mind centuries ago.

It is unfortunate therefore that Kiros condemned the refusal of the traditional African farmer to cut down certain forests as economically unintelligent. He argued that a reasonable African must not refuse to cut the trees. For him, "refusing to cut the trees so as to feed the hungry is foolish and destructive" (1992:127). Condemnations of this nature cannot be justified unless an effort is made to explore possible scientific or rational explanations for the attitude towards the sacred forest. 


\section{Response of the Church}

\section{Disregard for traditional beliefs and practices}

The response of the church in Ghana toward the traditional ways of conserving the ecosystem has not been good. The main reason is the type of Christianity planted on the Ghanaian soil. Christianity has been criticized for its role in environmental degradation. Lynn White, for example, has claimed that "especially in its Western form, Christianity is the most anthropomorphic religion the world has seen" (1967:1205). He argues that Christianity grounded its anthropocentric orientation in the text of Genesis where "God planned all of these explicitly for man's [sic] benefit and rule: no item in the physical creation had any purpose save to serve man's purposes" (1967:1205). Loader and other scholars contend that it is not Christianity or biblical faith that is to be blamed, but interpretation and emphasis of modern Christianity (Loader 1987:9).

Destructive action directed against Earth was grounded in a set of underlying hierarchal dualisms typical of Western thought. These dualisms are assumed to be part of reality: the 'natural' and 'normal' division of the world into male and female, mind and matter, reason and emotion, spiritual and material, heaven and earth, culture and nature. This way of thinking assumes a hierarchy in which the first component of the duality is superior to and more important than the second, and frequently leads to domination of the second by the first (Habel 2000:30).

Philosophers and scientists of the $17^{\text {th }}$ and $18^{\text {th }}$ centuries pressed the dualism of medieval Christianity to its logical conclusion. They perceived Earth as a machine, God as the great designer and humans as beings fashioned to determine the workings of the machine and run it for the benefit of human beings.

Because Earth and women have traditionally been associated on the same side of these dualistic pairings, this resulted in a disregard for the importance of the rights of both Earth and women. When Earth has been viewed as female, as 'Mother Earth' or as 'Mother Nature', Earth has often been oppressed and abused, and denied any status as a subject in its own right (Habel 2000:42).

Within much of traditional Western Christianity, therefore, people perceive the wonders of Earth as but a foretaste of the glories to be experienced in heaven. Western Christianity paid relatively little attention to whether natural resources or non-human life cycles were declining. After all, Earth was disposable matter - Earth would eventually become waste, destroyed as God's cosmic incinerator.

It was this type of Christianity that arrived in Ghana. The early resident Christian missionaries in Ghana planted Europe-made Christianity and established made-in-Europe churches. These missionaries "condemned African customs and institutions and taught social norms of nineteenth-century Europe as though they crystallized a moral code of universal validity" (Belhag and El-Kabir 1986:251). In Ghana the missionaries separated their converts from their local communities to distant places called salems or quarters. In the name of formal education, these converts were taught to frown upon their cultural beliefs and practices, including the observance of sacred days and adherence to the taboos.

Before the advent of the missionaries, the elders imparted moral and religious education with clear precepts reinforced by taboos. But the missionaries dismissed such notions as mumbo-jumbo and forcibly imposed religious beliefs that originated in the desert and had nothing to say about the African environment. The old taboos were stamped out, and before long the forests began to be systematically destroyed (Ajayi 1965:133). It is an eco- 
catastrophe from which Africa has never recovered; many Africans and specifically Ghanaian Christians have picked up and are continuing on this course today.

The antagonistic attitude of the early Western missionaries toward the indigenous beliefs and practices still persists in the church. The rise of Neo-Evangelical churches has worsened the matter. With much emphasis on the power of the Holy Ghost against anything cultural, Ghanaian Christians violate environment taboos with impunity. For them the taboos and other traditional practices are devilish. For most part, Ghanaian Christians see the traditional beliefs and practices as the arena to display their spiritual authority. It is common to find Christians violating environmental taboos to prove their so-called authority invested in them by God.

It is worth mentioning an experience of Wangari Maathai, the Kenyan environmentalist who won the Nobel Peace Prize in 2004. Wangari speaks of one particular tree near her village that she loved. She states:

That tree inspired awe, it was protected, it was the place of God. But in the 60s, after I had gone far away, I went back to where I grew up, and I found God has been relocated to a little stone building called a church. The tree was no longer sacred. It had been cut down. I mourned for that tree (Hari 2010).

This sense of grief at seeing a forest destroyed in the name of church building is saner than our shrugging. Similarly, it is sad to say, as Garbrah (2000:70) reports, that crocodiles which were in a pond near the Ghana Water Sewerage Corporation water treatment site at Bolgatanga have all been poached, when the inhabitants discovered that they could hunt for the crocodiles without incurring any spiritual harm. The disrespect for indigenous beliefs and practices, for me, is lack of biblical knowledge, for the Bible contains environmental taboos.

\section{Some Biblical Taboos on the Environment}

First, there are laws regarding animal welfare. Humans are commanded to rest on the seventh day and to ensure that their animals do the same: on the seventh day you shall cease from labour, in order that your ox and your ass may rest (Deut 5:14). In addition, no animal was to be slaughtered on the same day as its young. An animal's young was not to be boiled in its mother's milk. The law forbids the mating of two different types of animals for constancy of species. Moreover, since parts of animals function as food for humanity God put many limitations on their consumption. An example is the prohibition against eating the limbs of a living animal (Deut 12:23).

Second is the law of the land. As human beings and animals are given their times of Sabbath rest, so also is the land. Exodus 23:10 commands, "For six years you shall sow your land and gather in its yields; but the seventh year you shall let it rest and lie fallow..." The land Sabbath gives cultivated fields a chance both to rest and return vital nutrients to the soil, allowing it to produce bountifully for an indefinite time. This law enhances the quality of the produce, which leads to healthier people and livestock. Everybody benefits.

Third, in Lev 19:23-25 there are laws regarding the growth and producing of fruit trees designed for the mutual benefit of humans and trees. God does not even allow armies to cut down all the trees around a city when they need to besiege it (Deut 20:19-20). They must leave the fruit and nut trees intact! His law also proscribes the use of differing varieties of seed in a field, which more often than not 'defiles' or weakens the resultant produce (Deut 22:9).

Fourth, there is a law about a bird's nest with eggs or chicks in it (Deut 22:6-7): 
If you come across a bird's nest beside the road, either in a tree or on the ground, and the mother is sitting on the young or on the eggs, do not take the mother with the young. You may take the young, but be sure to let the mother go, so that it may go well with you and you may have a long life.

All these prohibitions and laws served environmental conservation. Putting differences in context (environmental differences) between ancient Israel and the Akan and also differences in the religious interpretations of these environmental contexts aside, there are similarities between Ghanaian indigenous beliefs and practices in ecosystem conservation and those of the Old Testament. It is unfortunate, therefore, that the Ghanaian Christian put too literal meaning on certain traditional requirement, thus failing to appreciate the traditional beliefs and taboos.

\section{A Way Forward for the Church}

The church can respond positively to the use of traditional beliefs and practices in ecosystem conservation as follows:

1. The church should seek to be biblical and African rather than European in thinking and practice. This calls for a redefinition of its identity as Ghanaian church. The church should strip away its European garment with its accompanied ideology that frowns upon the beliefs and practices of the indigenous people that helped to check environmental degradation. After all, the Bible contains taboos from God that were to be adhered to by his people to save their lives and their environment.

2. The church should learn about the indigenous beliefs and practices to find out the wisdom behind them, rather than dismissing them as devilish. This means it should become involved in festivals and other traditional events to understand the social implications of various rituals and taboos. The church should know that although some taboos may be a consequence of the symbolical or mythological qualities that the indigenous ascribe to animals, water bodies and plants, conservation motives behind such taboos should not be ruled out.

3. The church should help to preserve and utilize indigenous knowledge to protect fish stocks and coastal habitats, and animals and land habitats. This can be done by helping to collect, disseminate and systematize indigenous knowledge, taking into account the specific context in which it developed and exists and by working closely with traditional leaders.

4. In order to make indigenous knowledge on natural resource management sustainable, the church should draw up strategies to support the use of indigenous knowledge in natural resources management. This should include incorporating indigenous knowledge systems into their Junior and Senior High schools, Seminary and Bible College programmes and church preaching and teaching activities.

\section{Conclusion}

The study has shown that indigenous groups adapt to their natural environment in ways that conserve both their ecosystems and themselves as an integrated social-ecological system. It is clear that locally based human subsistence practices may enhance species richness. Species, resources, and global biodiversity very well may be negatively affected by the decay of adaptive traditional resource practices and linked social mechanisms such as taboos. This illuminates the importance of a deeper understanding of the resource conservation practices and social mechanism of traditional societies. This article has analysed the role of 
indigenous Akan beliefs and practices and their associated taboos. It is time the church rediscovers the importance of the indigenous beliefs and practices on ecosystem conservation and upholds them. Observing the taboos of the groves, for instance, does not in itself make one a pagan, if the observance is based on the conviction that the groves are necessary for ecological reasons and not on fear. Truly, science plays a major role in environmental protection, but the quasi-mystical taboos were an early and crude form of science, accumulated over time, to conserve the ecosystem. By the taboos, chiefs, elders, medicine men and priests interfered directly with hunting, fishing, gathering and most other harvesting activities. They prohibited the killing of certain animals and fishes in a restricted area whenever they thought that a certain species was too low in abundance. They were powerful agents in the control and management of resources (Ntiamoa-Baidu 1991; Wilson 1993). The church should seek to respect these traditional environmental agents and work with them in ecosystem conservation.

\section{BIBLIOGRAPHY}

Adu-Gyamfi, Y 2007. Leviticus 16 and Asante Odwira Festival: A Comparative Analysis with Reference to Christian Witness in Ghana. Unpublished PhD Thesis. The University of Sheffield.

Ajiyi, JF 1965. Christian Missions in Nigeria 1841-1891. London: Longman.

Akyeampong, Emmanuel and Pashington Obeng 1995. "Spirituality, Gender, and Power in Asante History." The International Journal of African Historical Studies 28, no. 3:481-508.

Asante, Emmanuel 1995. Towards an African Christian Theology of the Kingdom: The Kingship of Onyame. Lewiston: The Edwin Mellen Press.

Assimeng, M 1981. Social Structure of Ghana. Accra: Ghana Publishing Corporation.

Belhag, Ramadan S and El-Kabir Yassin A (eds.) 1986. Christian Missionarism and the Alienation of the African Mind. Dar Iqra, Tripoli.

Berkes, F, C Folke, and M Gadgil 1995. Traditional Ecological Knowledge, Biodiversity, Resilience, and Sustainability. Pages 281-299 in CA Perrings, K-G Mäler, C Folke, CS Holling, and B-O Jansson (eds.) Biodiversity Conservation: Problems and Policies. Dordrecht, Netherlands: Kluwer Academic Publishers.

Caillois, R 1980. Man and the Sacred. Translated by M Barash. Westport, Connecticut: Greenwood.

Carmichael, DL, J Hubert, B Reeves and A Schanche 1994. Sacred Sites, Sacred Places. London: Routledge.

Cassier, E 1992. An Essay on Man. New Haven: Yale University Press.

Chapman, M 1985. Environmental Influences on the Development of Traditional Conservation in the South Pacific Region. Environmental Conservation 12:217-230.

---- 1987. Traditional Political Structure and Conservation in Oceanic. Ambio 16;201-205.

Cummins, G and Whiteduck, K 1998. Towards a Model for the Identification and Recognition of Sacred Sites. Pages 3-14 in Sacred Lands. Edited by J Oakes, R Riewe, K Kinew and E Maloney. Alberta: University of Alberta.

Davidson, LK and Dunn-Wood, M 1993. Pilgrimage in the Middle Ages - A Research Guide. London: Garland Publishing. 
Durkheim, E 2001. The Elementary Forms of Religious Life. Translated by KE Fields. New York: Free Press.

Edgerton, RB 1992. Sick Societies: Challenging the Myth of Primitive Harmony. New York: The Free Press.

Eliade, M 1957. The Sacred and the Profane. Translated by WR Trask. London: Hartcourt.

--- 1958. Pattern of Comparative Religion. New York: Sheed \& Ward.

Ezeanya, SN 1969. God, Spirits and the Spirit World. Pages 30-46 in BiblicalRevelation and African Beliefs. Edited by Kwesi A Dickson and Paul Ellingworth. London: Lutterworth.

Frazer, JG 1926. The Worship of Nature. London: Macmillan.

Gadgil, M 1987. Social Restraints on Exploiting Nature: The Indian Experience. Development: Seeds of Change 1:26-30.

Garbrah, BW 2000. The Ecological Implications of Some Akan Traditional practices and Festivals. Trinity Journal of Church and Theology Vol 10. No. 1\&2:63-73.

Gupta, SS 1980. Sacred Trees across Cultures and Nations. Calcutta: Indian Publications.

Gyekye, Kwame 1987. An Essay on African Philosophical Thought: The Akan Conceptual Scheme. Cambridge: Cambridge University Press.

Habel, Norman 2000. Introducing the Earth Bible. Pages 25-37 in Reading from the Perspective of Earth. Edited by Norman Habel. Sheffield: Sheffield Academic Press.

Hari, J 2010. The Valley of Taboos. Slate, Monday, October. http://www.slate.com/id/2272098/.

Hubert, J 1998. Sacred Beliefs and Beliefs of Sacredness. Pages 9-19 in Sacred Sites, Sacred Places. Edited by DL Carmichael, J Hubert, B Reeves and A Schanche. London: Routledge.

Johannes, RE 1978. Traditional Marine Conservation Methods in Oceania and their Demise. Annual Review of Ecology and Systematics 9:349-364.

---- 1982. Traditional Conservation Methods and Protected Marine Areas in Oceania. Ambio 5:258-261.

---- 1984. Marine Conservation in Relations to Traditional Lifestyle of Tropical Artisanal Fishermen. The Environmentalist 4 (supplement 7):30-35.

Kiros, Tedros 1992. Moral Philosophy and Development: The Human Condition in Africa. Ohio: Ohio University Press.

Loader, James 1987. Image and Order: Old Testament Perspectives on the Ecological Crisis. Pages 6-28 in Are We Killing God's Earth? Edited by D Worster. Pretoria: University of South Africa.

Ntiamoa-Baidu, Yaa (1991). Conservation of Coastal Lagoons in Ghana: The Traditional Approach. Landscape and Urban Planning 20:41-46.

---- 2008. Indigenous Beliefs and Biodiversity Conservation: The Effectiveness of Sacred Groves, Taboos and Totems in Ghana for Habitat and Species Conservation. Journal for the Study of Religion, Nature and Culture 3:309-326.

Rea, AM 1981. Resource Utilization and Food taboos of Sonoran Desert Peoples. Journal of Ethnobiology 1:69-83.

Sinha, BC 1979. Tree Worship in Ancient India. London: East-West Publications.

Wilson, A 1993. Sacred Forest and the Elders. Pages 244-248 in Indigenous Peoples and Protected Areas. Edited by E Kemf. London: Earthscan. 